\title{
Anaerobic degradation of anionic surfactants by indigenous microorganisms from sediments of a tropical polluted river in Brazil
}

Iolanda Cristina Silveira Duarte ${ }^{1 *}$, Paula de França ${ }^{1}$, Dagoberto Yukio Okada ${ }^{2}$, Pierre Ferreira do Prado $^{1} \&$ Maria Bernadete Amancio Varesche ${ }^{2}$

1. Federal University of São Carlos - Campus Sorocaba, Department of Biology, João Leme dos Santos Highway (SP 264),110, 18052-780 Sorocaba, SP, Brazil; iolanda.duarte@gmail.com, paula_defranca@yahoo.com.br, pierreprado@hotmail.com

2. University of São Paulo, Department of Hydraulics and Sanitation, Trabalhador São-carlense Avenue 400, 13566-590 São Carlos, SP, Brazil; dagokada@gmail.com, varesche@sc.usp.br

\author{
Received 25-II-2014. C Corrected 21-VII-2014. Accepted 21-VIII-2014.
}

\begin{abstract}
Linear alkylbenzene sulfonate (LAS) is widely used in the formulation of domestic and industrial cleaning products, the most synthetic surfactants used worldwide. These products can reach water bodies through the discharge of untreated sewage or non-effective treatments. This study evaluates the ability of the microorganisms found in the Tietê river sediment to degrade this synthetic surfactant. The experiment was conducted in a bioreactor, operated in batch sequences under denitrifying conditions, with cycles of 24 hours and stirring at $150 \mathrm{rpm}$, using $430 \mathrm{~mL}$ of sediments and $1070 \mathrm{~mL}$ of a synthetic substrate consisting of yeast extract, soluble starch, sodium bicarbonate and sucrose. LAS was added at different concentrations of $15 \mathrm{mg} / \mathrm{L}$ and $30 \mathrm{mg} / \mathrm{L}$. The reactor operation was divided into the biomass adaptation to the synthetic substrate without LAS and three experimental conditions: a) addition of $15 \mathrm{mg} / \mathrm{L}$ of LAS; b) $50 \%$ reduction the co-substrate concentration and $15 \mathrm{mg} / \mathrm{L}$ of LAS, and c) addition of $30 \mathrm{mg} / \mathrm{L}$ of LAS and $100 \%$ co-substrate concentration. The results showed that the degradation efficiency of LAS was directly related to the addition of co-substrates and the population of denitrifying bacteria. The removal of LAS and nitrate can be achieved simultaneously in wastewater with low organic loads. The reduction in the co-substrates concentration was directly influenced by the number of denitrifying bacteria $\left(2.2 \times 10^{13}\right.$ to $\left.1.0 \times 10^{8} \mathrm{MPN} / \mathrm{gTVS}\right)$, and consequently, LAS degradation $(60.1$ to $55.4 \%)$. The sediment microorganisms in the Tietê river can be used as an alternative inoculum in the treatment of wastewater with nitrate and LAS contamination. Rev. Biol. Trop. 63 (1): 295-302. Epub 2015 March 01.
\end{abstract}

Key words: anaerobic, surfactant, degradation, bacteria, nitrate.

Linear alkylbenzene sulfonate (LAS) is the most important anionic surfactant used as an active ingredient in household and industrial cleaning agents. In 2008 the global production of surfactants was 13 million tonnes and approximately $65 \%$ of the total production corresponds to anionic surfactants (Olkowska, Ruman, Polkowska, 2014). LAS is a mixture of isomers containing an aromatic ring that is sulfonated at the para position. The LAS homologues contain a linear alkyl chain attached at any position except the terminal carbon
(Garcia, Campos, Sanchez-Leal, \& Ribosa, 2006). Statistics from the Council of European Surfactant Producers (CESIO) indicate a consumption of two million tons of surfactants in Europe for the year 1999. Within this total, linear alkylbenzene sulfonates (LAS), alkyl ethoxy sulfates (AES), alcohol ethoxylates (AEO) and alkyl sulfates (AS), account for 310000 , 237000,220000 and 102 000tons, respectively. LAS is typically discharged into the environment from sewage treatment stations or directly (Garcia et al., 2006). Currently, LAS 
concentration has been reported to vary from 1 to $18 \mathrm{mg} / \mathrm{L}$ in wastewater treatment plants (WWTP) (APHA, 2005), and up to $10 \mathrm{mg} / \mathrm{L}$ in coastal waters close to untreated discharges (Leon et al., 2002); nevertheless, LAS can also be found in river sediments (Berna et al., 2007) at concentrations between 0.4 to $4.7 \mathrm{mg} / \mathrm{Kg}$ (Cavalli et al., 2000). In a review, Olkowska et al. (2014) showed average values of anionic surfactants in sediment samples from rivers, lakes and seas, at a concentration of 0.0002$3.4 \mathrm{mg} / \mathrm{Kg}$. LAS concentrations are higher in sediments than in water (Olayemi, Eniola, Awe, \& Kayoe-Isola, 2003), thus the bacteria found in sediments are exposed to detergents.

In Brazil over $90 \%$ of domestic effluents is not discharged to a sewage treatment system. This untreated sewage is discharged into rivers, as seen by the abundance of xenobiotic surfactants in sanitary sewage (Eichhorn, Rodríguez, Baumann, \& Knepper, 2002). The Tietê River, which runs through the city of São Paulo (Brazil), is considered to be one of the most polluted rivers in the world, due to inefficient treatment and launching of clandestine industrial effluents. Mortatti, Moraes and Kiang (2012) analyzed various metals (copper, cobalt, chromium, zinc, nickel and lead) and different depths $(0$ to $30 \mathrm{~cm})$ of the Tietê river sediment. It is observed that the higher metal concentrations were copper (26.6 to $248.9 \mu \mathrm{g} / \mathrm{g}$ ), chromium $(85.8$ to $147.8 \mu \mathrm{g} / \mathrm{g})$ and zinc $(253.4$ to $780.0 \mu \mathrm{g} / \mathrm{g})$.

Nowadays, despite these discharges little is known about the potential of water and metabolism of sediment microorganisms in those rivers (Rocha et al., 2009). As for now, the linear alkylbenzene sulfonate (LAS) concentrations of $1.6 \mathrm{mg} / \mathrm{L}$ have been reported in the town of Pirapora do Bom Jesus along the Tietê river (Hatamura, Eysink, Bevilacqua, \& Moraes, 1993); also the Tamanduateí river in the city of São Paulo, which showed $2.3 \mathrm{mg} / \mathrm{L}$ of LAS (CESTEB, 1992), Macacu River (state of Rio de Janeiro - Brazil) showed lower concentrations of LAS $(14-155 \mu \mathrm{g} / \mathrm{L})$ (Eichhorn et al., 2002). Nevertheless, there is little additional information available about LAS concentration in other Brazilian rivers.

Microbial degradation of organic compounds occurs in anoxic sediments and soils, where the microorganisms utilize different electron acceptors (nitrate, sulfate and carbon dioxide and iron). However, xenobiotics in anoxic environments can be persistent due to the following factors: low solubility, toxicity and low biomass concentration (Elsgaard, 2010). The present study used microorganisms from Tietê river sediments contaminated with detergents, to promote LAS degradation, in a sequence batch reactor in denitrifying conditions.

\section{MATERIALS AND METHODS}

Inoculum: Sediment of Tietê River was used as inoculum for the degradation of the anionic surfactant in a bioreactor. An amount of $1.22 \mathrm{~kg}$ of sediment was collected in the city of Salto-SP (Brazil) $\left(23^{\circ} 00^{\prime} 44.8^{\prime \prime} \mathrm{S}-47^{\circ}\right.$ 00'17.2" W) in July (dry season) using a Van Veen dredge. The location was chosen due to the documented pollution exposure and intense foaming on the surface of the river at this specific point. This sediment was stored in plastic bags and kept refrigerated $\left(6^{\circ} \mathrm{C}\right)$ until use, including characterization of the physicochemical and microbiological properties (Table 1).

Anionic surfactant: The linear alkylbenzene sulfonate used in the present study was a commercial mixture of $\mathrm{C} 10-\mathrm{C} 13$ homologues provided by Aldrich (CAS no. 25155-30-0, technical grade).

Bioreactor: The schema of this bioreactor is shown in figure 1. The reactor was made of borosilicate glass, with a total volume of 1 $500 \mathrm{~mL}$. Stirring was done with an impellertype turbine, with three $14 \mathrm{~cm}$ blades and agitation at $150 \mathrm{rpm}$.

The substrate on the feed line was kept under refrigeration $\left(4^{\circ} \mathrm{C}\right)$ for conservation and was heated in a water bath $\left(30^{\circ} \mathrm{C}\right)$ before being discharged into the reactor. Peristaltic pumps were used to feed and discharge the effluent. 
TABLE 1

Analyzed parameters in the water and sediment of the Tietê River, in Salto-SP, Brazil

\begin{tabular}{lcc}
\multicolumn{1}{c}{ Parameters } & Results & References \\
Temperature $\left({ }^{\circ} \mathrm{C}\right)$ & 20.10 & \\
$\mathrm{pH}$ & 7.08 & \\
Conductivity $(\mathrm{mS} / \mathrm{cm})$ & 0.373 & \\
Dissolved Oxygen $(\mathrm{mg} / \mathrm{L})$ & 6.20 & \\
$\mathrm{TS}(\mathrm{g} / \mathrm{L})$ & 159.70 & APHA $(2005)$ \\
$\mathrm{TVS}(\mathrm{g} / \mathrm{L})$ & 31.60 & APHA $(2005)$ \\
LAS dissolved $(\mathrm{mg} / \mathrm{L})$ & 0.60 & Duarte et al. $(2006)$ \\
LAS adsorbed $(\mathrm{mg} / \mathrm{g})$ & $<0.30$ & Duarte et al. $(2008)$ \\
Nitrate $(\mathrm{mg} / \mathrm{L})$ & 2.66 & APHA $(2005)$ \\
Nitrite $(\mu \mathrm{g} / \mathrm{L})$ & 0.82 & APHA $(2005)$ \\
Denitrifying bacteria(MPNg/TVS) & $7.6 \times 10^{12}$ & Tiedje (1982) \\
\hline
\end{tabular}

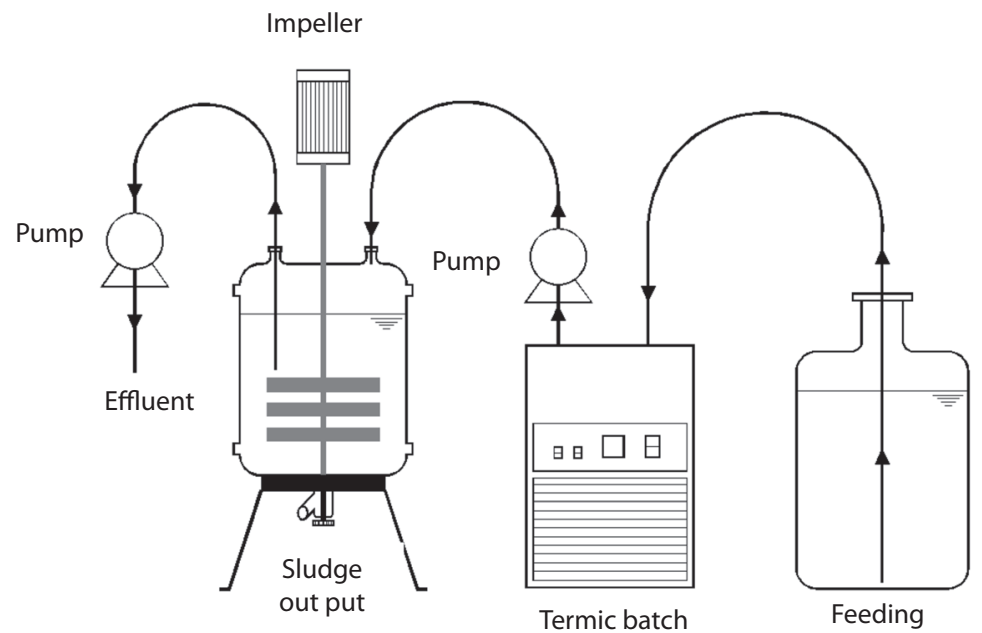

Fig. 1. Scheme of the mechanically stirred anaerobic sequencing batch.

Thus, we used $430 \mathrm{~mL}$ of Tietê river sediment (inoculum) and $1070 \mathrm{~mL}$ synthetic substrate.

The bioreactor was monitored for 144 days with defined 24-hour cycles. Each cycle was divided into four phases: 1) Feed without stirring (15min), 2) Reaction with stirring (23h), 3) Sedimentation without stirring (30min) and 4) Output of treated effluent (drain of reactor) without stirring (15min).

The synthetic substrate in the feed line consisted of yeast extract, sucrose, sodium bicarbonate $\left(\mathrm{NaHCO}_{3}\right)$, starch, potassium nitrate $\left(\mathrm{KNO}_{3}\right)$ and liquid household detergent (quantified as LAS concentration) (Table 2).
During the 144 cycles, the bioreactor showed different stages: biomass adaptation to synthetic substrates - 39 days; (A) LAS addition $(15 \mathrm{mg} / \mathrm{L})-31$ days; (B) decrease in co-substrates $(50 \%)-61$ days; (C) increase in LAS concentration $(30 \mathrm{mg} / \mathrm{L})-43$ days. Chemical oxygen demand (COD) (raw and filtered), nitrate and solids were determined according to APHA (2005). The $\mathrm{pH}$ of the suspension was determined with a $\mathrm{pH}$ meter.

The LAS concentration was periodically measured in the liquid phase (influent and effluent) using high-performance liquid chromatography (HPLC) (Duarte, Oliveira, Buzzini, 
TABLE 2

Synthetic substrate composition during stages in sequence batch reactor

\begin{tabular}{cccccccc} 
Stage & Time (days) & Yeast extract $(\mathrm{mg} / \mathrm{L})$ & Sucrose $(\mathrm{mg} / \mathrm{L})$ & $\mathrm{NaHCO}_{3}(\mathrm{mg} / \mathrm{L})$ & Starch $(\mathrm{mg} / \mathrm{L})$ & $\mathrm{KNO}_{3}(\mathrm{mg} / \mathrm{L})$ & $\mathrm{LAS}(\mathrm{mg} / \mathrm{L})$ \\
adaptation & 39 & 500 & 80 & 400 & 230 & 200 & - \\
A & 31 & 500 & 80 & 400 & 230 & 200 & 15 \\
B & 61 & 250 & 40 & 400 & 115 & 250 & 15 \\
C & 43 & 500 & 80 & 400 & 230 & 250 & 30 \\
\hline
\end{tabular}

Adorno, \& Varesche, 2006). The adsorbed LAS was extracted with methanol in an ultrasound bath for 30 minutes and analyzed by HLPC HPLC in triplicate (Duarte, Oliveira, Saavedra, Fantinatti-Garboggini, Oliveira, \& Varesche, 2008). This extraction protocol had an efficiency of $85 \%$ (Duarte et al., 2008). The mass balance for LAS considered the surfactant in the feed (influent), in the effluent and adsorbed on the biomass in the reactor.

The most probable number (MPN) technique was used to estimate the denitrifying bacteria (Tiedje, 1982) in the biomass reactor. The biomass reactor samples were homogenized and diluted in flasks with the feeding solution used in each operational stage. The detection of bacteria was performed after 30 days of incubation at $30^{\circ} \mathrm{C}$. The results were interpreted as detailed by APHA (2005).

\section{RESULTS}

The sediment used as inoculum for surfactant degradation showed high density of denitrifying bacteria $-7.6 \times 10^{12} \mathrm{MNP} / \mathrm{gTVS}$ (Table 1).

In the adaptation stage, the bioreactor showed stability with influent $\mathrm{pH}$ of 6.3 and effluent of 7.3. At this stage, the COD removal was $69 \%$ for COD influent and effluent of $382 \mathrm{mg} / \mathrm{L}$ and $129 \mathrm{mg} / \mathrm{L}$, respectively. However, the nitrate removal achieved was $98 \%$ with an estimation of denitrifying bacteria of $7.6 \times 10^{10} \mathrm{MNP} / \mathrm{gTVS}$. Solids loss was observed when compared to the initial bioreactor operation conditions (13.6 to 6.9gTVS).

With the addition of $15 \mathrm{mg} / \mathrm{L}$ of LAS (stage A), the nitrate, $\mathrm{COD}$ removal and $\mathrm{pH}$ were not affected (Table 3). In this stage, $675 \mathrm{mg}$ of LAS were added in the reactor. After this stage, mass balance indicated that the addition of $10 \%$ LAS was adsorbed on the biomass and LAS degradation was $60 \%$ (Table 4). Denitrifying bacteria population was improved by adding LAS and the population was estimated at $2.2 \times 10^{13} \mathrm{MPNg} / \mathrm{TVS}$, and the amount of solids in the reactor also increased from 6.9 to 7.3gTVS. Stage B lasted 61 days and was characterized by a $50 \%$ decrease of organic sources (co-substrates) and $1440 \mathrm{mg}$ addition of LAS. The effluent $\mathrm{pH}$ remained stable; the nitrate removal was reduced to $84 \%$ of efficiency; also there was a decrease of COD removal efficiency (37\%), LAS degradation (55.4\%), estimation of denitrifying bacteria $\left(1.0 \times 10^{8} \mathrm{MNP} /\right.$ gTVS) and solids (4.9gTVS) (Table 3 ).

Due to the decrease in the population of denitrifying bacteria, and in the efficiency of LAS degradation, concentrations of co-substrates were re-established, and the concentration of LAS increased to $30 \mathrm{mg} / \mathrm{L}$. Stage C had the highest mass of LAS applied (1 944mg) and showed the highest specific LAS-load rate (9.7mgLAS/gTVS/d). The effluent $\mathrm{pH}$ and the most probable number of denitrifying bacteria remained similar to the previous stage, the COD removal efficiency increased to $57 \%$. Even resuming to the previous nutritional conditions, the total volatile solids $(3.2 \mathrm{~g})$ and nitrate removal (Table 3) decreased, and the degradation efficiency of LAS was the lowest observed during the experiment, reaching $47 \%$ (Table 4). It is probable that the addition of $30 \mathrm{mg} / \mathrm{L}$ LAS and removal of co-substrates were negative concerning LAS removal in the system (Fig. 2). 
TABLE 3

Mean values of the monitoring parameters

\begin{tabular}{|c|c|c|c|c|}
\hline \multirow{2}{*}{ Parameter } & \multicolumn{4}{|c|}{ Stages } \\
\hline & adaptation & A & B & $\mathrm{C}$ \\
\hline \multicolumn{5}{|l|}{ COD } \\
\hline Influent (mg/L) & $382 \pm 208$ & $350 \pm 150$ & $154 \pm 61$ & $324 \pm 71$ \\
\hline Effluent (mg/L) & $129 \pm 115$ & $130+88$ & $96 \pm 43$ & $139 \pm 32$ \\
\hline \multicolumn{5}{|l|}{ Nitrate } \\
\hline Influent (mg/L) & $180 \pm 2$ & $200 \pm 23$ & $226 \pm 23$ & $255 \pm 29$ \\
\hline Effluent (mg/L) & $3 \pm 2$ & $15 \pm 24$ & $35 \pm 12$ & $55 \pm 13$ \\
\hline \multicolumn{5}{|l|}{ LAS } \\
\hline Influent (mg/L) & & $15.0 \pm 1.0$ & $15.0 \pm 1.0$ & $30.0 \pm 3.0$ \\
\hline Effluent (mg/L) & & $4.8 \pm 1.6$ & $6.1 \pm 2.0$ & $14.6 \pm 3.4$ \\
\hline Specific LAS load rate (mgLAS gTVS/d) & & 2.06 & 3.09 & 9.70 \\
\hline \multicolumn{5}{|l|}{ pH } \\
\hline Influent & $6.5 \pm 0.7$ & $6.9 \pm 0.5$ & $7.7 \pm 0.2$ & $7.7 \pm 0.3$ \\
\hline Effluent & $7.3 \pm 0.2$ & $7.4 \pm 0.3$ & $7.5 \pm 0.1$ & $7.7 \pm 0.1$ \\
\hline Solid Total (g/L) & $26.7 \pm 1.5$ & $23.6 \pm 1.5$ & $14.3 \pm 2.8$ & $7.2 \pm 8.2$ \\
\hline Total volatile (g/L) & $6.9 \pm 1.0$ & $7.3 \pm 1.0$ & $4.9 \pm 1.0$ & $3.2 \pm 1.0$ \\
\hline Denitrified bacteria (MPN/gTVS) & $7.6 \times 10^{10}$ & $2.2 \times 10^{13}$ & $1.0 \times 10^{8}$ & $2.4 \times 10^{8}$ \\
\hline
\end{tabular}

TABLE 4

Mass balance of LAS in sequence batch reactor

\begin{tabular}{lccc}
\multicolumn{1}{c}{ Mass balance } & \multicolumn{3}{c}{ Stages } \\
& A & B & C \\
Added - influent (mg) & 675 & 1440 & 1944 \\
Effluent(mg) & 202 & 566 & 953 \\
Adsorbed (mg) & 67 & 77 & 77 \\
Degraded (mg) & 406 & 798 & 914 \\
Degradation efficiency (\%) & 60.1 & 55.4 & 47.0 \\
Removal (\%) & 68.2 & 59.3 & 51.2 \\
Time (d) & 30 & 60 & 42 \\
\hline
\end{tabular}

\section{DISCUSSION}

Due to their high consumption and applications, significant amounts of surfactants are released into the environment, and this release causes serious problems in rivers and oceans. High concentrations of surfactants can be found in river sediments receiving untreated effluents due to inefficient degradation of LAS. Eniola and Olayemi (2008) found surfactant concentrations ranging from 45 to $132 \mathrm{mg} / \mathrm{g}$ in sediments from the Asa River in

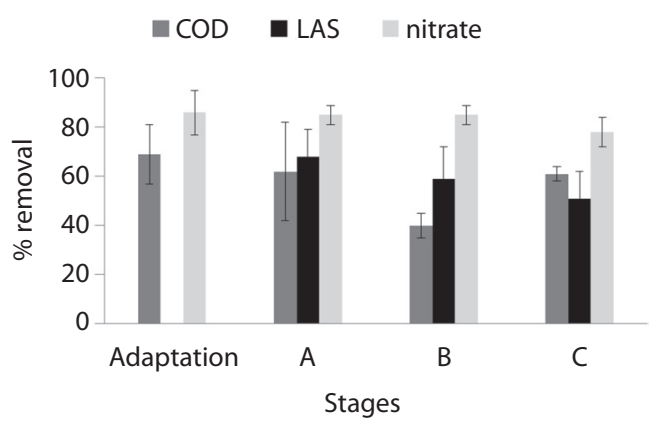

Fig. 2. Percentages of COD, nitrate and LAS removal in different stages.

Nigeria and heterotrophic bacteria $2.9 \times 10^{5}$ and $1.2 \times 10^{7} \mathrm{CFU} / \mathrm{g}$.

The sediment analyzed in this study showed concentrations of LAS lower than $0.30 \mathrm{mg} / \mathrm{g}$ of sediment, however, the population of denitrifying bacteria was $7.6 \times 10^{12} \mathrm{MPN} /$ gTVS, showing that denitrifying bacteria are responsible for nitrate reduction processes in river sediments (Berna et al., 2007).

Also, biological systems using pure cultures or microbial consortia in different fermentation conditions have been used to promote the 
degradation of surfactants (Cserháti, Forgács, Oros, 2002). This bioavailability increase was remarkable at the beginning of LAS addition, because of the organic compounds previously adsorbed on the biomass. According to Elsgaard (2010), the presence of LAS $(105 \mathrm{mg} / \mathrm{L})$ in wastewater does not inhibit nitrate removal, but inhibits iron sulfate removal.

In our study, it is possible that the nutritional conditions enriched some bacteria from the inoculum, increasing microorganisms which use LAS as carbon source. Decreased co-substrates affected the degradation efficiency of LAS $(55.4 \%)$ possibly due to a lower denitrifying bacteria population estimated $\left(1.0 \times 10^{8} \mathrm{MPNg} / \mathrm{TVS}\right)$. Furthermore, biomass concentration decreased from 7.3gTVS/L (stage A) to $4.9 \mathrm{gTVS} / \mathrm{L}$ (stage B). Also, mean nitrate removal decreased from $87 \%$ (stage A) to $78 \%$ (stage $\mathrm{B}$ ).

LAS degradation under denitrifying conditions observed in this study was higher than any other reported at the same LAS concentration. An anaerobic sequence batch reactor achieved LAS degradation efficiency of $37-53 \%$, related to a LAS concentration in the influent of $22 \mathrm{mg} / \mathrm{L}$ and specific-LAS load rate ranging from 6.8 to $9.8 \mathrm{mgLAS}$ g/TVS, the highest LAS degradation was $53 \%$ in the stage without co-substrates (Duarte, Oliveira, Mayor, Okada, \& Varesche, 2010). The LAS presence did not inhibit bacteria in an acidogenic Upflow Anaerobic Sludge Blanket (UASB) reactor. After 250 days, LAS degradation was $41 \%$. At hydraulic retention time of $6 \mathrm{~h}$, this reactor used lactose $(1 \mathrm{~g} / \mathrm{L})$ as co-substrate. Potassium nitrate was the electron acceptor at 1:1 ratio (LAS: NO3-) and this acceptor was completely consumed (Almendariz, Meráz, Soberón, \& Monroy, 2001).

A UASB reactor fed with isotonic solution and LAS $(5 \mathrm{mg} / \mathrm{L})$ degraded $85 \%$ of the surfactant. In this study, another UASB reactor fed with co-substrates showed LAS degradation of $64 \%$ (Sanz, Culubret, de Ferrer, Moreno, \& Berna, 2003). Moreover, UASB reactors under mesophilic and thermophilic conditions obtained removal rates ranging from 40 to $80 \%$
(Lobner, Torang, Batstone, Schmidt, \& Angelidaki, 2005). The test batches lasting 165 days, which used marine sediments as inoculum for LAS degradation (concentration ranging from 10 to $50 \mathrm{mg} / \mathrm{L}$ ) resulted in LAS degradation of $79 \%$ and identified high phylogenetic variety in the process. Clone library showed the classes Alphaproteobacteria, Gammaproteobacteria (genus Pseudomonas), and Sedimentibacter (family Clostridiales) (Lara-Martin, GomezParra, Kochling, Sanz, Amils, \& GonzalezMazo, 2007).

Tietê river sediments could be used as inoculum in reactors for the treatment of anionic detergents in denitrifying (anaerobic redox potential) conditions. Denitrifying bacteria are potential candidates for effective anaerobic degradation of LAS. This bacteria group was able to degrade LAS molecule independently of additional carbon sources, while removing chemical oxygen demand and nitrate in anaerobic wastewater treatment plants.

\section{ACKNOWLEDGMENTS}

We gratefully acknowledge the Conselho Nacional de Pesquisa (CNPq) for funding this study, (Process 479900/2008-6).

\section{RESUMEN}

Degradación anaeróbica de tensioactivos aniónicos en microorganismos autóctonos de los sedimentos de un río tropical contaminado en Brasil. El alquilbenceno sulfonato lineal (LAS) es el tensoactivo sintético más usado en todo el mundo en los produtos de limpeza domestica e industrial y puede llegar a las masas de agua a través de la descarga de aguas residuales sin tratamiento o con un tratamiento ineficaz. El objetivo del estudio consistió en evaluar la capacidad de la microbiota presente en el sedimento del río Tietê en la degradación del tensoactivo anionico - LAS. El experimento se llevó a cabo en un bioreactor de lotes secuenciales en condiciones de desnitrificación con ciclos de 24 horas, agitación de $150 \mathrm{rpm}$, usando $430 \mathrm{~mL}$ de sedimento y $1070 \mathrm{~mL}$ de sustrato sintético constituido por extracto de levadura, almidón soluble, bicarbonato de sodio y sacarosa. El LAS fue añadido a diferentes concentraciones de $15 \mathrm{mg} / \mathrm{L}$ y $30 \mathrm{mg} / \mathrm{L}$. El funcionamiento del bioreactor se dividió en la adaptación de la biomasa con sustrato sintético sin LAS y tres condiciones experimentales: A) adición de $15 \mathrm{mg} / \mathrm{L}$ 
de LAS; B) $15 \mathrm{mg} / \mathrm{L}$ de LAS y reducción del $50 \%$ de la concentración del co-sustrato y C) $30 \mathrm{mg} / \mathrm{L}$ de LAS y la concentración de $100 \%$ de co-substrato. Los resultados obtenidos muestran que la eficiencia en la degradación del LAS está directamente relacionada con la población de bacterias desnitrificadoras y que el sedimento del río Tietê se puede utilizar como inóculo en el tratamiento de LAS en condiciones desnitrificadoras. La población de bacterias fue capaz de degradar el LAS independiente de la fuente de carbón adicionada. La remoción de LAS y de nitrato se puede lograr simultáneamente en aguas residuales con una baja carga orgánica. La reducción de la concentración del co-sustrato fue influenciado directamente por la población de bacterias desnitrificantes $\left(2.2 \times 10^{13}\right.$ a $1.0 \times 10^{8} \mathrm{MNP} /$ gTVS) y por lo tanto la degradación de LAS (60.1-55.4\%). Los microorganismos en el sedimento del río Tietê se pueden usar como inóculo alternativo para el tratamiento de efluentes contaminados con nitrato y LAS.

Palabras clave: LAS, anaeróbico, tensioactivo, degradación, bacterias, nitrato.

\section{REFERENCES}

Almendariz, F. J., Meráz, M., Soberón, G., \& Monroy, O. (2001). Degradation of linear alkylbenzene sulphonate (LAS) in an acidogenic reactor bioaugment UIT a Pseudomonas aeroginousa (M113) strain. Water Science Technology, 44, 183-188.

American Public Health Association (APHA), American Water Works Association (AWWA), Water Environment Federation (WEF). (2005). Standard Methods for the Examination of water and wastewater. Washington DC: American Public Health Association.

Berna, J. L., Cassini, G., Hager, C. D., Rehman, N., López, I., Schowanek, K. D., Sterber, J., Taeger, K., \& Wind, T. (2007). Anaerobic biodegradation of surfactantsScientific Review. Tenside Surfactants Detergents, 44, 312-346.

Cavalli, L., Cassani, G., Vigaró, L., Pravettoni, S., Nucci, G., Lazzarin, M., \& Zatta, A. (2000). Surfactants in sediments. Tenside Surfactactants Detergents, 37, 282-288.

CETESB - Companhia Ambiental do Estado de São Paulo. (1992). Água do mar - Teste de toxicidade crônica de curta duração com Lytechinus variegatus, Lamarck, 1816. Norma Técnica L5.250. São Paulo: CETESB.

Cserháti, T., Forgács, E., \& Oros, G. (2002). Biological activity and environmental impact of anionic surfactants. Environmental International, 28, 337-348.
Duarte, I. C. S., Oliveira, L. L., Buzzini, A. P., Adorno, M. A. T., \& Varesche, M. B. A. (2006). Development of a method by HPLC to determine LAS and its application in anaerobic reactors. Journal of the Brazilian Chemical Society, 17, 1360-1367.

Duarte, I. C. S., Oliveira, L. L., Saavedra, N. K. D., Fantinatti-Garboggini, F., Oliveira, V. M., \& Varesche, M. B. A. (2008). Evaluation of the microbial diversity in a horizontal-flow anaerobic immobilized biomass reactor treating linear alkylbenzene sulfonate. Biodegradation, 19, 375-385.

Duarte, I. C. S., Oliveira, L. L., Mayor, M. S., Okada, D. Y., \& Varesche, M. B. A. (2010). Degradation of detergent (linear alkylbenzene sulfonate) in an anaerobic stirred sequencing-batch reactor containing granular biomass. International Biodeterioration and Biodegradation, 64, 129-134.

Elsgaard, L. (2010). Toxicity of xenobiotics during sulfate, iron, and nitrate reduction in primary sewage sludge suspension. Chemosphere, 79, 1003-1009.

Eichhorn, P., Rodríguez, S. V., Baumann, W., \& Knepper, T. P. (2002). Incomplete degradation of linear alkylbenzene sulfonate surfactants in Brazilian surface waters and pursuit of their metabolites in drinking waters. Science of Total Environmental, 284, 123-134.

Eniola, K. I. T., \& Olayemi, A. B. (2008). Linear alkylbenzene sulfonate tolerance in bacteria isolated from sedimento $f$ tropical water bodies polluted with detergents. Revista Biologia Tropical, 56, 1595-1601.

Garcia, M. T., Campos, E., Sanchez-Leal, J., \& Ribosa, I. (2006). Effect of linear alkylbenzene sulphonate (LAS) on the anaerobic digestion of sewage sludge. Water Research, 40, 2958-2964.

Hatamura, E., Eysink, G. J., Bevilacqua, J. E., \& Moraes, R. P. (1993). Enriquecimento das espumas por substâncias químicas como agente de exportação de poluentes no Rio Tietê. (Relatório Técnico). CETESB.

Lara-Martin, P. A., Gomez-Parra, A., Kochling, T., Sanz, J. L., Amils, R., \& Gonzalez-Mazo, E. (2007). Presence, biotransformation and effects of sulfophenylcarboxylic acids in the benthic fish Solea senegalensis. Environment International, 33, 565-570.

Lobner, T., Torang, L., Batstone, D. J., Schmidt, J. E., \& Angelidaki, I. (2005). Effects of process stability on anaerobic biodegradation of LAS in UASB reactors. Biotechnology Bioengineering, 89, 759-765.

Mortatti, J., Moraes, G. M., \& Kiang, C. H. (2012). Distribuição e possível origem de metais pesados nos sedimentos de fundo ao longo da Bacia do alto Tietê: aplicação da normalização geoquímica sucessiva. Geociências, 31, 175-184. 
Olayemi, A. B, Eniola, K. I. T., Awe, S., \& Kayoe-Isola, M. T. (2003). Distribution of Bacteria in three detergent effluent-polluted water bodies in Ilorin, Nigeria. Nigeria Society for Experimental Journal, 3, 79-86.

Olkowska, E., Ruman, M., \& Polkowska, Z. (2014). Occurrence of surface active agents in the environment. Journal of Analytical Methods in Chemistry, 2014, $1-15$.

Rocha, P. S., Luvizotto, G. L., Kosmehl, T., Bottcher, M., Storch, V., Braunbeck, T., \& Hollert, H. (2009). Sediment genotoxicity in the Tietê River (São Paulo, Brazil): in vitro comet assay versus in situ micronucleus assay studies. Ecotoxicolology and Environmental Safety, 72, 1842-1848.

Sanz, J. L., Culubret, E., De Ferrer, J., Moreno, A., \& Berna, J. L. (2003). Anaerobic biodegradation of linear alkylbenzene sulfonate (LAS) in up-flow anaerobic sludge blanket (UASB) reactors. Biodegradation, 14, 57-64.

Tiedje, J. M. (1982). Denitrification. In A. Page, R. H. Miller, \& D. R. Keeney (Eds.), Methods of soil analysis (pp. 1011-1026). Winsconsin: American Society of Agronomy. 